\title{
The Age, Education, and Occupation Characteristics is not Associated with Human Immunodeficiency Virus (HIV) Infection in Pregnant Mothers
}

\author{
Usia, Pendidikan, dan Pekerjaan tidak Berhubungan dengan Infeksi \\ Human Immunodeficiency Virus (HIV) pada Ibu Hamil
}

\author{
Kade Y Saspriyana, Ketut Suwiyoga, I Made Darmayasa \\ Obstetrics and Gynecology Department \\ Faculty of Medicine University of Udayana/ \\ RSUP Sanglah Hospital \\ Denpasar
}

\begin{abstract}
Objective: To know the relationship between age, education and occupation on the pregnant women and the HIV status of the husband against the risk of being infected with HIV.

Method: This was an unpaired case control study performed in the Obstetrics and Gynecology Department of Sanglah Hospital, Denpasar, from October to November 2011. The subjects were pregnant women who were willing to participate in the research, which were grouped into HIV-infected case and control group. Diagnosis of HIV was based on rapid test. The data was analyzed using Chi Square test with the help of SPSS version 17.0
\end{abstract}

Result: There was fifty subjects consisting of 25 subjects in the case group and 25 subjects in control group we obtained that the risk of HIV-infected pregnant women in the old vs young age, low vs higher education, and occupations at risk vs not at risk is not significant in the two groups. Each Odds ratio is $0.35(\mathrm{CI}=95 \% 0.08-1.55 ; \mathrm{p}=$ $0.16), 0.85(\mathrm{CI}=95 \% 0.28-2.59 ; \mathrm{p}=0.77)$, and 2.09 ( $\mathrm{CI}=95 \% 0.18$ 24.62; $p=1.00)$. Meanwhile, the odds ratio of the husband HIV status was $12.67(\mathrm{CI}=95 \%$ 3.31-48.50; $\mathrm{p}=0.01)$.

Conclusion: Husbands infected with HIV increases the risk of HIV in pregnant women 12 times greater than if the husband was not infected with HIV. Whereas, age, education, and the occupation of mothers is not a risk factor for the occurrence of HIV infection in pregnant women.

[Indones J Obstet Gynecol 2014; 2: 65-68]

Keywords: age, education, husband HIV status, occupation and pregnant women infected with HIV.

\begin{abstract}
Abstrak
Tujuan: Mengetahui apakah usia, pendidikan, dan pekerjaan pada ibu hamil serta status HIV suami sebagai faktor risiko ibu hamil terinfeksi HIV.

Metode: Berupa kasus kontrol tidak berpasangan di Bagian Obstetri dan Ginekologi RSUP Sanglah Denpasar selama dua bulan, yaitu bulan Oktober-November 2011. Sampel adalah ibu hamil terinfeksi HIV sebagai kelompok kasus dan tanpa infeksi HIV sebagai kelompok kontrol. Diagnosis HIV ditegakkan dengan rapid test serum, yaitu dinyatakan positif kalau reaktif dan negatif kalau non reaktif. Analisis data memakai uji Chi Square dengan bantuan SPSS for windows 17.0 version untuk mengetahui rasio Odds.
\end{abstract}

Hasil: Lima puluh sampel dibagi atas 25 kelompok kasus dan 25 kelompok kontrol. Diperoleh bahwa risiko terinfeksi HIV perempuan hamil pada usia tua vs muda, pendidikan tinggi vs rendah, dan pekerjaan berisiko vs tidak berisiko adalah tidak bermakna pada kedua kelompok. Rasio Odds masing-masing adalah 0,35 (KI 95\% = 0,081,55; $p=0,16), 0,85$ (KI 95\% = 0,28-2,59; $p=0,77)$, dan 2,09 (IK 95\% $=0,18-24,62 ; p=1,00)$. Sedangkan, rasio Odds status HIV suami adalah 12,67 (KI 95\% = 3,31-48,50; $p=0,01)$.

Kesimpulan: Suami terinfeksi HIV meningkatkan risiko HIV pada ibu hamil 12 kali lebih besar dibandingkan dengan suami tidak terinfeksi HIV. Sedangkan, faktor usia, pendidikan, dan pekerjaan ibu bukan merupakan faktor risiko terjadinya infeksi HIV pada ibu hamil.

[Maj Obstet Ginekol Indones 2014; 2: 65-68]

Kata kunci: ibu hamil terinfeksi HIV, pekerjaan, pendidikan, status HIV suami, usia.

Correspondence: Kade Y Saspriyana, Jln. Badaksari III/1, Sumerta Kelod, Denpasar, HP. 081338769747,

Email: saspriyana@yahoo.co.id

\section{INTRODUCTION}

The etiologyof Acquired Immunodeficiency Syndrome (AIDS) is Deoxyribonucleic Acid (DNA) retroviral which known as Human Immunodeficiency Virus (HIV). ${ }^{1}$ The risk factor of HIV transmission is sexual activity through an unprotected sexual intercourse with infected human, blood transfusion, drugs injection with shared needle, medical procedure that is not sterile, and transmission from the mother to the baby during pregnancy, delivery, and breastfeeding. ${ }^{2}$ The prevalence of AIDS in Bali was 85.95 in 100.000 population. ${ }^{3}$

There are some factors influencing HIV transmission and contributing to the incidence of HIV infection. These factors are highly individual, including racial or ethnic disability in facing the pressure or problems. The other factor is politic policy. Law also plays a role either directly or indirectly. The last factor is warfare, which could result in health infrastructure damage, poverty, and social instability in the conflict area. ${ }^{4}$ 
It is possible that the chain of HIV transmission begun from an HIV positive male who transmitted the infection to their wives or their sexual partners through an unprotected sexual intercourse. Then the wives or sexual partners could transmit the virus transplacentally to the their babies during pregnancy. Thus, it is important to know the male's infection status. ${ }^{5}$

Epidemiologic profiles of HIV in pregnancy that is linked to increasing risk in HIV transmission from man to woman are age, study level, and occupation. Health knowledge and promotion could also be associated with HIV transmission. Inability to acquire enough income can drive people to some occupation that has a high risk for HIV transmission. ${ }^{6-8}$

\section{METHOD}

This was an unpaired case control study performed in the Obstetrics and Gynecology Department of Sanglah Hospital, Denpasar, from October to November 2011. The subjects were pregnant women who were willing to participate in the research, which were grouped into HIV-infected case and control group. Diagnosis of HIV was based on rapid test examination.

Next, the subject was identified based on age, educational level, occupation, and husband HIV status. For the husband HIV status, we did confirmation to VCT clinic to check the accuracy of the data. We did analysis for all of these epidemiology characteristics to know if they could be a risk factor for HIV infection in pregnant women in Bali.

Data was analyzed using the Chi Square test with the help of SPSS version 17.0. Shapiro Wilk test was performed to know the normality of data distribution. Then Chi-Square test was performed to acquire the odds ratio.

\section{RESULTS}

This research used case control method. The sample were 50 pregnant women, with 25 HIV-infected women grouped as cases and 25 women with no HIV infection grouped as control. The subjects in case group were pregnant women with HIV positive which follow PMTCT program in Sanglah Hospital Denpasar and the subjects in control group were pregnant with HIV negative which had antenatal care at Sanglah Hospital Denpasar.

Table 1. Sample Characteristic based on Case and Control Group

\begin{tabular}{lccccc}
\hline \hline \multirow{2}{*}{ Variable } & \multicolumn{4}{c}{ Group } & p \\
\cline { 2 - 4 } & \multicolumn{4}{c}{ Case $(\mathrm{n}=25)$} & \multicolumn{1}{c}{ Control $(\mathrm{n}=25)$} \\
\hline Age (year) & 26.84 & 4.17 & 24.48 & 5.12 & 0.080 \\
Parity & 1.44 & 0.96 & 1.36 & 0.91 & 0.763 \\
\hline \hline
\end{tabular}

Based on t-independent test, Table 1 showed that $p$ value $>0.05$. It means there was no significant difference between case and control group based on age and parity status.

Table 2 showed correlation between husband HIV status and pregnant women infected with HIV. Husband HIV status increase risk factor to get infected with HIV 12 times (OR = 12.67, CI 95\% = 3.31-48.50, $\mathrm{p}=0.001$ ).

Table 2. Correlated between Husband HIV Status and Pregnant Women Infected with HIV.

\begin{tabular}{|c|c|c|c|c|c|c|}
\hline & & \multicolumn{2}{|c|}{ Group } & \multirow{2}{*}{ OR } & \multirow{2}{*}{ CI 95\% } & \multirow{2}{*}{$\mathbf{p}$} \\
\hline & & Case & Control & & & \\
\hline \multirow[t]{2}{*}{ Husband HIV Status } & HIV $(+)$ & 19 & 5 & \multirow{2}{*}{12.67} & \multirow{2}{*}{$3.31-48.50$} & \multirow{2}{*}{0.001} \\
\hline & HIV $(-)$ & 6 & 20 & & & \\
\hline
\end{tabular}


Table 3. Correlated between Age, Educational Level, Occupation, and Pregnant Women Infected with HIV.

\begin{tabular}{|c|c|c|c|c|c|c|}
\hline & & \multicolumn{2}{|c|}{ Group } & \multirow{2}{*}{ OR } & \multirow{2}{*}{ CI 95\% } & \multirow{2}{*}{$\mathbf{p}$} \\
\hline & & Case & Control & & & \\
\hline \multirow[t]{2}{*}{ Age } & Young & 18 & 22 & \multirow[t]{2}{*}{0.35} & \multirow{2}{*}{$0.08-1.55$} & \multirow{2}{*}{0.157} \\
\hline & Old & 7 & 3 & & & \\
\hline \multirow[t]{2}{*}{ Educational Level } & Low & 11 & 12 & \multirow[t]{2}{*}{0.85} & \multirow[t]{2}{*}{$0.28-2.59$} & \multirow[t]{2}{*}{0.777} \\
\hline & High & 14 & 13 & & & \\
\hline \multirow[t]{2}{*}{ Occupation } & High Risk & 2 & 1 & \multirow[t]{2}{*}{2.09} & \multirow[t]{2}{*}{$0.18-24.62$} & \multirow[t]{2}{*}{1.00} \\
\hline & Low Risk & 23 & 24 & & & \\
\hline
\end{tabular}

Table 3 showed there was no correlation between age and pregnant women infected with HIV (OR $=0.35$, CI 95\% $=0.08-1.55, \mathrm{p}=0.157)$. As well as no correlation between educational level and pregnant women infected with HIV (OR $=0.85$, CI $95 \%=0.28-2.59, \mathrm{p}=0.777)$. It also showed there was no correlation between occupation and pregnant women infected with HIV (OR $=2.09$, CI 95\% $=0.18-24.62, \mathrm{p}=1.00$ ).

\section{DISCUSSION}

Based on analysis, we found average of age in case group was $26.84 \quad 4.17$ and average of age in control group was $24.48 \quad 5.12$, with p value $=0.080$. It mean there was no age difference between case and control group. Parity average for case group was $1.44 \quad 0.96$ and for control group was 1.36 0.91 , with $\mathrm{p}$ value $=0.763$, meaning there was no parity difference between case and control group.

We obtained that the risk of HIV-infected pregnant women in the old vs young age, low vs higher education, and occupations at risk vs not at risk is not significant in the two groups. Each Odds ratio is $0.35(\mathrm{CI}=95 \% 0.08-1.55 ; \mathrm{p}=0.16), 0.85(\mathrm{CI}=$ $95 \% 0.28-2.59$; $\mathrm{p}=0.77$ ), and 2.09 (CI $=95 \% 0.18$ 24.62; $\mathrm{p}=1.00$ ). Meanwhile, the Odds ratio of the husband HIV status was 12.67 (CI $=95 \%$ 3.3148.50; $\mathrm{p}=0.01$ ).

Therefore husbands infected with HIV increases the risk of HIV in pregnant women 12 times greater than if the husband was not infected with HIV. Whereas, age, education, and the occupation of mothers is not a risk factor for the occurrence of HIV infection in pregnant women.

\section{CONCLUSION}

Husband infected with HIV increases the risk of HIV in pregnant women 12 times greater than if the husband was not infected with HIV. Whereas, age, education, and the occupation of mothers is not a risk factor for the occurrence of HIV infection in pregnant women.

\section{REFERENCES}

1. Leveno KJ, Cunningham FG, Alexander JM, Bloom SL, Casey BM, Dashe JS, Sheffield JS. Human Immunodeficiency Virus. In: Leveno KJ editor. Williams Manual of Obstetrics Pregnancy Complications. 22 ${ }^{\text {nd }}$ Ed. United States of America: McGraw-Hill. 2008: 420-5.

2. Allworth A, Anderson J, Andrews P, Beers K, Bradford D, Bramwell M, Brotherton A. Exposure and acute HIV infection. In: Dore G, Grulich A, Hoy J, Kidd M, McCoy R, Mijch A, Strasser S editors. HIV/Viral Hepatitis a guide for primary care. $1^{\text {st }}$ Ed. Adelaide: Finsbury Printing. 2004: 30-6.

3. Kementerian Kesehatan Republik Indonesia. Statistik Kasus HIV/AIDS di Indonesia dilapor sampai dengan Maret 2013. Kementerian Kesehatan Republik Indonesia. (online article), [cited 3 Juli 2013]. Available from: URL: http://spiritia.or.id/Stats/StatCurr.pdf

4. Poundstone KE, Strathdee SA, Celentano DD. The Social Epidemiology of Human Immunodeficiency Virus/Acquired Immunodeficiency Syndrome. Epidemiol Rev 2004. (serial online), June, [cited 2011 Feb. 23]. Available from: URL: http://epirev.oxfordjournals.org/content/26/1/22.full.pd f+html

5. Pratomo H, Djauzi S, Naing AM, Anwar AD, Besar DS, Setiabudi D, Resmiati F. Faktor Risiko Penularan HIV Dari Ibu ke Bayi. In: Pratomo H editor. Pedoman Nasional Pencegahan Penularan HIV Dari Ibu ke Bayi. Departemen Kesehatan Republik Indonesia: Direktorat Jenderal Bina Kesehatan Masyarakat, 2006: 13-8.

6. Sagay AS, Kapiga SH, Imade GE, Sankele JL, Idoko J, Kanki P. HIV infection among pregnant women in Nigeria. Int J Gynecol Obstet 2005. (serial online), March, [cited 2011 Mar. 13]. 
7. Kumar A, Bent V. Characteristics of HIV-infected childbearing women in Barbados. Pan Am J Public Health. 2003 (serial online), January, [cited 2011 Maret. 11]. Available from: URL: http://www.scielosp.org/pdf/rpsp/v13n1/ a01v13n1.pdf
8. Kwiek JJ, Mwapassa V, Alker AP, Muula AS, Misiri HE, Molyneux ME, Rogerson SJ, Behets FM, Meshnick SR. Sociodemographic characteristics associated with HIV and syphilis seroreactivity among pregnant women in Blantyre, Malawi, 2000-2004. Malawi Med J. 2008 (serial online), September, [cited 2011 Feb. 23]. Available from: URL: http://www.ajol.info/index.php/mmj/article/viewFile/10 $965 / 37749$ 